\title{
Effect of dietary protein level on in vivo and in vitro vitamin A esterase activity in the chick
}

\author{
BY I. NIR, I. BRUCKENTAL, I. ASCARELLI AND A. BONDI \\ Department of Animal Nutrition and Agricultural Biochemistry, Faculty of \\ Agriculture, Hebrew University, Rehovot, Israel
}

(Received 20 September 1966-Accepted 14 February 1967)

\begin{abstract}
I. The efficiency of absorption of and liver storage from a single oral dose of roooo i.u. vitamin A palmitate decreased in chicks reared on a diet containing $10 \%$ protein as compared. to the efficiency in chicks reared on a diet in which the protein level was adequate. When the chicks were given orally an equivalent dose of vitamin A alcohol, the absorption was equally efficient at both dietary protein levels.

2. The vitamin A alcohol content of the intestine, plasma and liver of chicks dosed with vitamin A palmitate was decreased by protein restriction. The physiological change responsible for this decrease seems to be the lowering of the hydrolysing activity for vitamin A palmitate in pancreas and in the duodenal mucosa.

3. The importance of this enzymic step in the absorption of an oral dose of vitamin A palmitate is shown by the finding that protein malnutrition reduced only slightly the final liver stores when vitamin $A$ in its different forms (palmitate, acetate or alcohol) was injected directly into the blood stream.

4. The uptake of injected vitamin $A$ from the blood was much delayed when the vitamin was injected as palmitate, i.e. the ester of a long-chain fatty acid, instead of the acetate ester or the free alcohol.

5. When vitamin A was injected, the liver content did not rise continuously with time, but showed a temporary decrease after a certain period. The phenomenon was apparently due to changes in the rate of the two inverse processes of uptake of the vitamin by the liver and liberation from it.
\end{abstract}

The interrelationship between dietary protein level and vitamin A ester hydrolysis in vitro and in vivo was studied in rats by Deshmukh, Malathi \& Ganguly (1964). They demonstrated that protein malnutrition reduced the hydrolysis of vitamin $\mathrm{A}$ acetate in rat intestine and that this reduction was related to reduced liver storage. In previous publications (Nir \& Ascarelli, 1966; 1967a) we have shown that protein malnutrition and thiouracil reduced in the chick the percentage of liver vitamin $\mathrm{A}$ found in the alcohol form, and that hyperthyroidism increased it. In all instances liver depletion and storage level were related to the percentage of free vitamin A present in the liver. We have also shown that high ambient temperatures, which are believed to increase vitamin $A$ requirements, also increased the percentage of free vitamin $\mathrm{A}$ in the liver ( $\mathrm{Nir} \&$ Ascarelli, $1967 \mathrm{~b}$ ). In the experiments of short duration reported here we have tested in vivo and in vitro the effect of dietary protein level on the activity of various tissues for the hydrolysis and synthesis of vitamin A esters. The examination of the different forms of the vitamin (ester and alcohol) in the organs at the different phases of absorption reveals that several steps may be involved in the malabsorption of the vitamin in protein-deficient chicks, the most important step being poor hydrolysis of vitamin A ester in the intestine. 


\section{EXPERIMENTAL}

\section{Animals and diets}

All chicks were crossbred male New Hampshire $\times$ White Leghorn. The management was as described by Nir \& Ascarelli (I966). The same basal diet, almost devoid of vitamin A-active ingredients, and the same semi-synthetic diets were given as described by Nir \& Ascarelli (1967a). The mean amount of vitamin A in liver after the depletion period was I0-30 i.u./liver. In all the experiments the birds were group-fed.

Expt I. Two-week-old chicks maintained on semi-synthetic diets containing $30 \%$ or I0\% protein and fortified with I00 i.u. vitamin A/I00 g were dosed with I I ooo i.u. water-dispersible vitamin A palmitate (Chas. Pfizer and Co. Inc., New York) after a I $6 \mathrm{~h}$ fast. By giving the dose as a coloured liquid and killing the chicks immediately after dosing, it could be seen that almost all of the liquid was introduced into the proventriculus. Four chicks in each treatment were killed by bleeding by heart puncture after different periods. The alimentary canal was divided into two parts: stomach (from mouth to pylorus) and intestine (from pylorus to anus). Each of these two parts of the alimentary canal, and the livers and blood plasma were analysed for vitamin A alcohol and ester. Vitamin A esterase activity of pancreas homogenates was determined in six chicks on each dietary protein level.

Expt 2. Two-week-old chicks maintained as in Expt I were dosed after a $\mathrm{I} 6 \mathrm{~h}$ fast with $\mathrm{I} \mathrm{ml}$ of a solution of vitamin A palmitate or alcohol (Hoffmann-La Roche \& Co., Basle, Switzerland) dissolved with the aid of Tween 80 and containing 10000 i.u. Five chicks from each treatment were killed according to the same schedule as in the previous experiment. In this experiment vitamin A was analysed in the different tissues of the chicks in pooled samples of five at each period. Vitamin A esterase activity in pancreas homogenates was determined in five chicks per treatment.

Expt 3. Two-week-old vitamin A-depleted chicks were dosed with roooo i.u. vitamin $\mathrm{A}$ as $\mathrm{I} \mathrm{ml}$ of three different solutions: ( $\mathrm{I}$ ) a commercial water-soluble vitamin A palmitate (Pfizer), (2) a Tween 80 solution of vitamin A palmitate (Hoffmann-La Roche), (3) a Tween 80 solution of crystalline vitamin A alcohol (Hoffmann-La Roche). Liver vitamin A was determined after $24 \mathrm{~h}$ in five chicks on each of the three treatments given either a $30 \%$ or $10 \%$ protein diet.

Expt 4. Chicks were depleted during 2 weeks of their vitamin A store and were then fed up to the age of 25 days on the basal diet fortified with 75 i.u. vitamin A/100 g. Their average weight was then $212 \mathrm{~g}$. They were then given $0^{\circ} \mathrm{I} \mathrm{ml}$ of a Tween 80 solution containing I0000 i.u. vitamin A acetate as an injection into the vena radialis. Liver vitamin $A$ and its partition in the alcohol and ester form were determined at different periods (Io, 20, 30,60 and $180 \mathrm{~min}$ ) after the injection. Five chicks were analysed at each period.

Expt 5. Chicks were depleted during 2 weeks of their vitamin A stores and were then fed for another 2 weeks on the semi-synthetic diets containing $5 \%, 10 \%$ or $30 \%$ protein and fortified with $100 \mathrm{i} . \mathrm{u}$. vitamin $\mathrm{A} / \mathrm{I} 00 \mathrm{~g}$. They were given injections of vitamin $\mathrm{A}$ acetate as in the previous experiment. Livers, kidneys and plasma were analysed 
10, 60, 180 min and $24 \mathrm{~h}$ after injection. Four chicks per treatment were analysed at each period. In vitro hydrolysis of vitamin A acetate was tested in the liver and kidney homogenates of four chicks per treatment.

Expt 6. Four-week-old chicks fed as in Expt 4 (mean body-weight $269 \mathrm{~g}$ ) were injected intravenously with a Tween 80 solution containing Io000 i.u. vitamin A alcohol or acetate. Plasma and liver were analysed at the same periods after injection as in the previous experiment, and also after $3 \mathrm{~min}$.

Expt 7. Chicks treated as in Expt 6, but omitting the 5\% protein diet, were injected intravenously with vitamin A alcohol or palmitate and analysed for their vitamin A contents in plasma and liver at the same periods as in the previous experiment. Three chicks per treatment were analysed. The capacity of pancreas and intestinal mucosa homogenates to hydrolyse or synthesize vitamin A palmitate was tested in five chicks at each protein level.

Expt 8. The effect of two different types of diet (our basal diet containing $22 \%$ protein and $3 \%$ fat and our semi-synthetic diet containing $30 \%$ protein and $10 \%$ fat) and of different amounts of Tween 80 injected with the vitamin were investigated. Chicks were reared on each of the above-mentioned diets, fortified with 300 i.u. vitamin A/ $100 \mathrm{~g}$, up to the age of 33 days. They were then injected intravenously with vitamin $A$ alcohol or vitamin A palmitate. The vitamin A alcohol solution was the same as in the previous experiment, i.e. contained vitamin $A$ alcohol and Tween 80 in a weight ratio of I : ro. Vitamin A palmitate was injected, at the same level, in one of two different solutions. In one the ratio of Tween 80 to vitamin A palmitate was $5: \mathrm{I}(\mathrm{w} / \mathrm{w})$ and in the other $I_{5}: \mathrm{I}$, as compared to the $10: \mathrm{I}$ ratio used in the previous experiments. All chicks were bled to death by heart puncture ro min after injection and the vitamin $\mathrm{A}$ alcohol and ester contents of the plasma were determined.

\section{Preparation of vitamin $A$ solutions and dosing techniques}

In Expts I, 2 and 4 a solution of commercial water-dispersible vitamin A palmitate (Pfizer) was given by mouth. In the other experiments aqueous solutions of the vitamin, given by mouth or injected into the blood stream, were prepared as described in the previous paper (Nir, Bruckental \& Ascarelli 1967). When given by mouth, I ml of the solution was given with a tuberculin syringe. When injected, $0.1 \mathrm{ml}$ of the solution was injected into the vena radialis with an Agla micrometer syringe.

\section{Analytical methods}

Extraction of vitamin A from liver or intestine was carried out with ethyl ether after dehydration with sodium sulphate, according to Ames, Risley \& Harris (1954). Stomachs (i.e. alimentary canal from mouth to pylorus) were first denatured by blending with an equal weight of ethanol in a Waring Blendor. Three extractions were then carried out in a Waring Blendor with light petroleum (b.p. $60^{\circ}-80^{\circ}$ ). The crushed tissue was separated each time from the solvent by filtering through a fritted glass filter. Analyses of the residue for vitamin A after saponification gave negative results.

Extraction of plasma vitamin A and separation of the vitamin A ester and alcohol 
were carried out as described by Nir \& Ascarelli (1966). Partition of the ester forms was carried out according to Jungalwala \& Cama (1962).

Vitamin A concentration was determined by the Carr-Price reaction. Protein in enzymic solution was determined by the biuret method as described by Gornall, Bardawill \& David (r949).

Enzymic assays. Preparation of enzyme solutions and enzymic media was carried out according to Nir et al. (ig67). The incubation time was $30 \mathrm{~min}$ for all tissues, apart from pancreas, for which, because of its high activity, incubation was reduced to I 5 min when its hydrolysing activity was tested. Amounts of substrates were about 300 i.u. vitamin A; only when the hydrolytic activity of pancreatic tissue was tested, was the amount of substrate raised to about 700 i.u. Results are expressed as \% product formed per mg protein, the total amount of vitamin recovered being taken as $100 \%$.

\section{RESULTS}

\section{Oral administration of vitamin $A$}

Expt $\mathrm{I}$. In this experiment the effect was tested of dietary protein level on the absorption of an oral dose of vitamin A palmitate. The results are presented in Table $\mathrm{x}$.

Most of the vitamin A had left the stomach 30 min after dosing in all the chicks. A certain amount of vitamin A alcohol could be found in the stomachs. The absorption from the intestine was obviously decreased at the low dietary protein level, and this malabsorption was concomitant with less hydrolysis of the vitamin A palmitate. The lowering in hydrolytic activity caused by protein malnutrition was found both in vivo, by determining the vitamin $\mathrm{A}$ alcohol percentage in the intestine, and in vitro, by the hydrolysis of vitamin A palmitate by pancreas homogenates, as shown in Table 2, in which in vitro values from other experiments are also summarized. Table 2 also shows that no difference was caused by protein malnutrition in the esterifying activity of pancreatic tissue.

Plasma vitamin A level attained a peak of 2900 i.u. $/ 100 \mathrm{ml}$ plasma 30 min after dosing in the chicks fed on the $30 \%$ protein diet, decreasing to 438 i.u. after $6 \mathrm{~h}$. In the chicks fed on the $10 \%$ protein diet a much lower peak was attained, and this only $3 \mathrm{~h}$ after dosing. It seems therefore that the relatively low level of plasma vitamin A found in the chicks fed on the low-protein diet was, at least partly, caused by delayed absorption from the intestine. The chicks fed on the $30 \%$ protein diet had already attained equilibrium $24 \mathrm{~h}$ after dosing, whereas the chicks fed on the $10 \%$ protein diet were not yet in equilibrium: their plasma vitamin A level was then 292 i.u./ $/ 00 \mathrm{ml}$ (higher than in the chicks fed on the $30 \%$ protein diet) but decreased to I 40 i.u./ I00 $\mathrm{ml}$ after $48 \mathrm{~h}$. With both treatments changes in plasma vitamin A level were due mainly to fluctuations in vitamin A ester content, the changes in vitamin A alcohol being comparatively small.

The storage of vitamin $\mathrm{A}$ in the liver was greatly influenced by dietary protein level. The chicks fed on the low-protein diet stored only $\mathrm{I} 48 \mathrm{I}$ i.u. as compared to the 4023 i.u. stored by the chicks fed on the $30 \%$ protein diet $24 \mathrm{~h}$ after dosing. Appreciable stores could be found in the chicks fed on the $30 \%$ protein diet as early as $30 \mathrm{~min}$ 
Vol. 2I

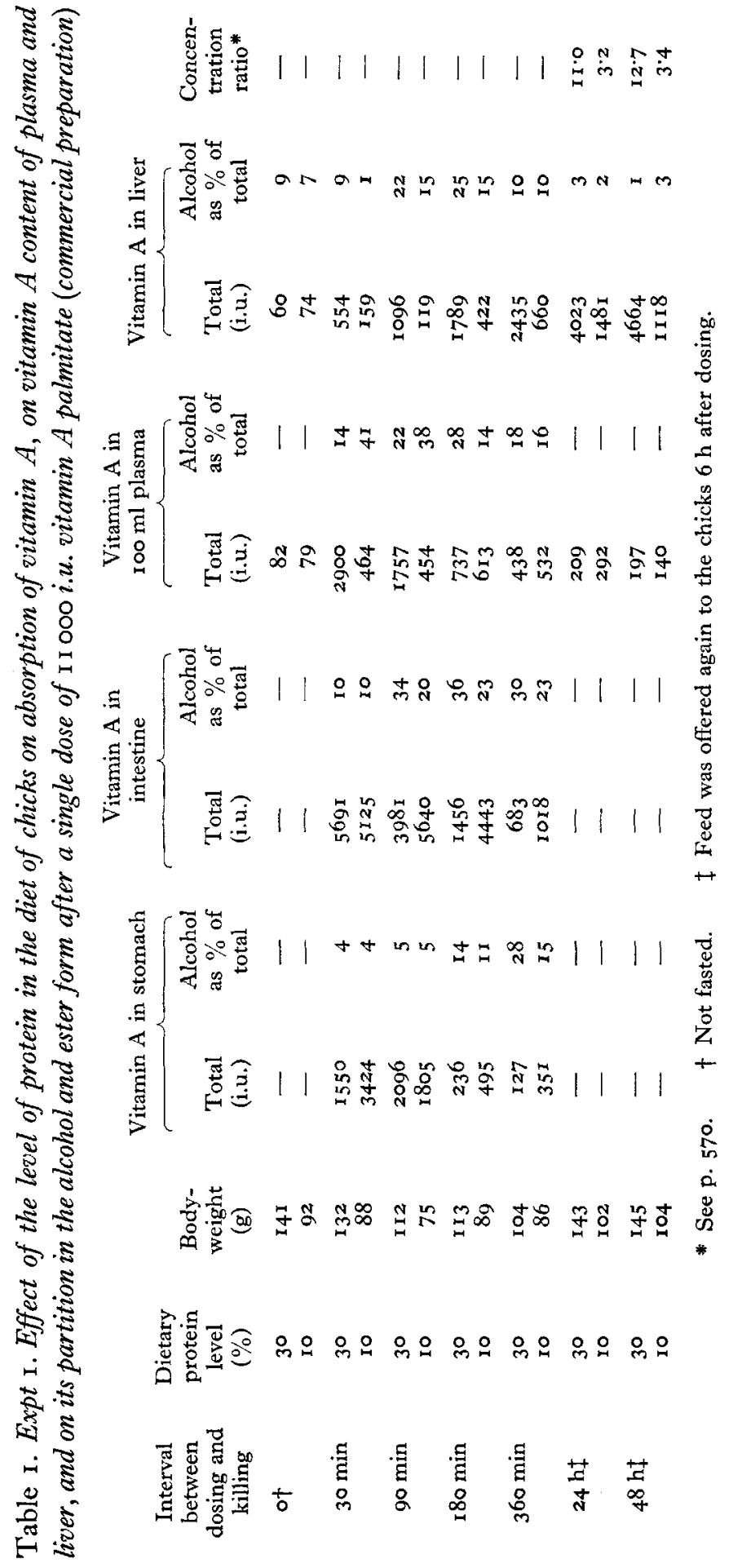


after dosing, and more than half of the final liver stores were attained after $6 \mathrm{~h}$. In the chicks fed on the 10\% protein diet appreciable stores could be found only $3 \mathrm{~h}$ after dosing.

The percentage of liver vitamin $\mathrm{A}$ in the alcohol form attained a maximum $3 \mathrm{~h}$ after dosing $(25 \%$ in the chicks fed on the $30 \%$ protein diet, and only $15 \%$ in the chicks fed on the $10 \%$ protein diet), but $24 \mathrm{~h}$ after dosing this percentage was already reduced to the usual 2-3\%. Expressing the level of vitamin A in tissues as concentration (i.u./g) did not change the conclusions reached by comparing the absolute amounts.

Table 2. Hydrolysis of vitamin $A$ palmitate and esterification of vitamin $A$ alcohol by homogenates of pancreas and duodenal mucosa of chicks given a diet with $30 \%$ or $10 \%$ protein

\begin{tabular}{|c|c|c|c|c|c|c|c|c|}
\hline \multirow{3}{*}{$\begin{array}{c}\text { Expt } \\
\text { no. }\end{array}$} & \multicolumn{4}{|c|}{ Hydrolysis $(\%) *$} & \multicolumn{4}{|c|}{ Esterification $(\%)^{*}$} \\
\hline & \multicolumn{2}{|c|}{ Pancreas } & \multicolumn{2}{|c|}{ Duodenal mucosa } & \multicolumn{2}{|c|}{ Pancreas } & \multicolumn{2}{|c|}{ Duodenal mucosa } \\
\hline & $30 \%$ & $10 \%$ & $30 \%$ & $10 \%$ & $30 \%$ & $10 \%$ & $30 \%$ & $10 \%$ \\
\hline $\mathbf{I}$ & 59 & 47 & - & - & 21 & 23 & - & - \\
\hline 2 & 42 & 26 & - & - & 26 & 17 & - & - \\
\hline 7 & 45 & $3^{8}$ & 9 & 3 & 31 & 30 & 4 & 2 \\
\hline
\end{tabular}

As has been shown previously (Nir \& Ascarelli, 1966), differences in body-weight of the order caused by the different treatments do not alter the quantity of vitamin A stored in the liver following the administration of a single dose. However, it is clear that the smaller chicks received a relatively larger dose when expressed as i.u. dose/g body-weight. This ratio represents in a rough way the concentration of the dose administered. In an attempt to eliminate the influence of body and liver sizes, we have compared this ratio to the final concentration of the vitamin in the liver (i.u./g). We shall call 'concentration ratio' the expression

$$
\frac{\text { Concentration of liver vitamin A (final) }}{\text { Concentration of dose }}=\frac{\text { i.u./g liver }}{\text { i.u. dose } / g \text { body-weight }} \text {. }
$$

The calculation of this ratio in the present experiment gives a value of 1.8 in the chicks fed at the high protein level and of only 3.3 in the chicks fed at the low protein level, again showing the lowering of the storing capacity caused by protein malnutrition.

Expt 2. The effect of dietary protein level on the absorption of vitamin A given as palmitate or alcohol was tested in this experiment: by this comparison we tried to clarify to what extent the decreased hydrolysis of vitamin A palmitate caused by protein malnutrition might interfere with absorption and storage.

The disappearance of vitamin A from the stomach was not delayed by protein malnutrition. Vitamin A alcohol was found in the stomachs of chicks dosed with the palmitate, and vitamin A ester was found in the stomachs of the chicks dosed with the alcohol. This finding points to the presence of vitamin A esterase activity in the 'stomach'. The same enzymic activities could be shown when the two vitamin A forms 
were incubated in excised organs (unpublished results): it is not clear if these findings are caused by the presence of some gastric enzyme or by regurgitation of duodenal juice through the pylorus.

As in the previous experiment, protein malnutrition caused a decreased absorption from the intestine when vitamin A was given as palmitate. However, there was no such effect when the alcohol was given. In Fig. I the amounts are given of total vitamin $A$ and vitamin $A$ alcohol found in the intestine at the different periods after

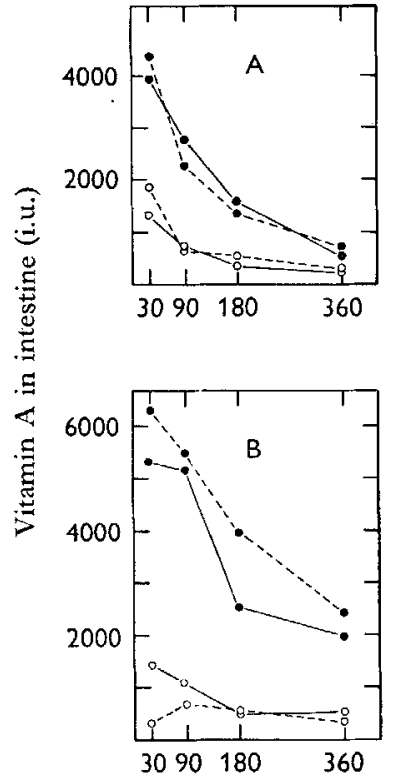

Time after dosing $(\mathrm{min})$

Fig. I

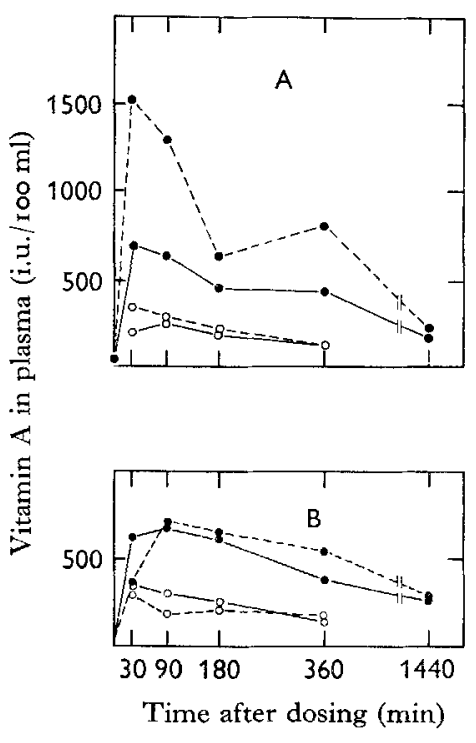

Fig. 2

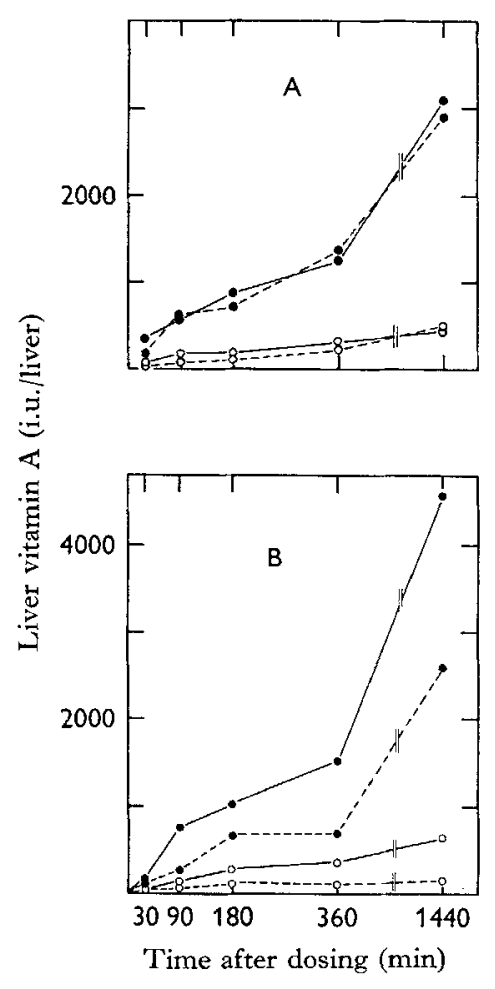

Fig. 3

Fig. I. Expt 2. Effect of the protein level in the diet of chicks on amounts of vitamin A in the intestine at different intervals after a single dose of 10000 i.u. vitamin A alcohol or palmitate. A, dosing with alcohol; $\mathrm{B}$, dosing with palmitate; -, 30\% dietary protein; - - , 10\% dietary protein; , total vitamin A; $O$, vitamin A alcohol.

Fig. 2. Expt 2. Effect of the protein level in the diet of chicks on amounts of vitamin $A$ in plasma at different intervals after a single dose of 10000 i.u. vitamin $\mathrm{A}$ alcohol or palmitate. All symbols as in Fig. I.

Fig. 3. Expt 2. Effect of the protein level in the diet of chicks on amounts of vitamin $A$ in liver at different intervals after a single dose of $10000 \mathrm{i} . \mathrm{u}$. vitamin A alcohol or palmitate. All symbols as in Fig. $\mathrm{I}$.

dosing (the amount of vitamin A ester can be easily estimated by difference). The picture here presented results from a dynamic state caused by the simultaneous inflow of vitamin from the stomach and outflow through absorption. At all periods chicks fed on the low-protein diet and dosed with vitamin A palmitate had higher levels of 
total vitamin $A$ and vitamin $A$ ester in their intestine than the chicks fed on the $30 \%$ protein diet. On the other hand, the vitamin $\mathrm{A}$ alcohol content in their intestine was lower during the first $2 \mathrm{~h}$ after dosing, but later on this level decreased in the chicks fed on the $30 \%$ protein diet and the absolute amounts of this form of the vitamin became equal in the chicks fed at both protein levels; however, as a percentage, vitamin A alcohol was much lower at all periods in the protein-deficient chicks.

When the vitamin was administered as alcohol, its disappearance from the intestine was greatly accelerated. Maybe this finding resulted in part from a faster destruction of the alcohol in the alimentary tract as compared to the palmitate which is more stable. However, this cannot be the main factor because, when the two forms of the vitamin were introduced into excised intestinal segments and incubated during $\mathrm{I} h$, the rate of destruction of the vitamin A alcohol was only slightly higher than that of the palmitate (unpublished results). The amounts of vitamin A ester formed in the intestine were reduced by protein malnutrition, but this reduction was not accompanied by reduced absorption from the intestine. As in the previous experiment, the hydrolytic activity of pancreas homogenates was reduced by protein malnutrition (Table 2). In this instance protein malnutrition also caused a marked reduction in the synthetic activity of pancreas homogenates.

The absorption curve in plasma (Fig. 2) was influenced by the dietary protein level. As in the previous experiment, when vitamin A palmitate was given, protein malnutrition delayed the rise in plasma level: the analytical results in the two experiments were quantitatively quite different but the trends were the same. The amount of vitamin $\mathrm{A}$ found as alcohol in plasma was reduced by protein malnutrition.

In chicks dosed with the alcohol, blood levels of vitamin A show that blood was not a limiting factor in the transport of the ester form after absorption from the intestine. In these chicks protein malnutrition increased the concentration of vitamin A ester in blood. A probable explanation of this finding is a slower uptake of the vitamin by the liver and by other tissues.

Protein malnutrition decreased liver vitamin $\mathrm{A}$ when the vitamin was given as palmitate, but to a smaller extent than in the previous experiment (since different vitamin A preparations were used in the two experiments, this point will be further clarified in the next experiment). No such effect of the protein restriction was found when the alcohol form was fed (Fig. 3). It is therefore obvious that the reduced hydrolytic activity in the intestine of protein-deficient chicks was involved in the malabsorption of the vitamin A palmitate. By comparing the final stores attained by the normal chicks, it can be seen that they were higher when the vitamin was supplied as palmitate than when it was supplied as the free alcohol.

The form of the vitamin that was administered had no effect on the percentage of the vitamin present as alcohol in the livers of the normal chicks. Protein malnutrition reduced this percentage at the $3 \mathrm{~h}$ and $6 \mathrm{~h}$ periods after dosing; this trend was still present in the chicks given vitamin A palmitate $24 \mathrm{~h}$ after dosing, but disappeared in those given vitamin A alcohol.

In accordance with the changes in total storage, the concentration ratio was reduced by protein deficiency, in the chicks given the palmitate, from $12 \cdot 7$ to $6 \cdot 3$, whereas 
there was no similar reduction in the chicks given the alcohol $(9.9$ and 9.6 at the $30 \%$ and $10 \%$ dietary protein levels, respectively).

Expt 3. By comparing the liver storage of the chicks dosed with vitamin A palmitate in Expts $I$ and 2, it can be seen that it was quite different in the protein-deficient chicks. As different dispersing media were used in the two experiments, namely a solution of commercial water-soluble vitamin A palmitate in Expt $\mathbf{I}$ and a Tween 8o solution of synthetic vitamin A palmitate in Expt 2, we thought it necessary to compare them directly in this experiment. We also administered a Tween 80 solution of crystalline vitamin $\mathrm{A}$ alcohol in order to test again if any better storage could be obtained by the use of this form in chicks fed at a low dietary protein level. With the palmitate preparations the liver stores were fairly close to those previously attained, namely $376 \mathrm{r}$ i.u. with the commercial preparation and 4432 i.u. with the Tween 80 solution. Protein malnutrition as usual decreased the liver stores, but the extent of the reduction was different with the two preparations, the liver stores being only I 708 i.u. after dosing with the commercial preparation, and $32.2 \mathrm{I}$ i.u. after dosing with the Tween 80 solution. When vitamin $A$ was administered in its alcohol form, the same liver storage was attained by the chicks fed on the $30 \%$ or 10\% protein diet ( 3892 i.u. and 3977 i.u. respectively). The concentration ratios were in this experiment of the same order as in Expts $\mathrm{I}$ and 2, and essentially reflected the better absorption of Tween solutions of vitamin A palmitate in protein malnutrition.

\section{Intravenous injection of vitamin $A$}

In the previous experiments we studied the function of the digestive tract in vitamin A absorption, and we have pointed out the importance of the hydrolysis of vitamin A esters in the intestine in the pre-absorptive phase. In the following experiments we have by-passed the influence of the digestive tract by injecting the vitamin directly into the blood stream. By this technique we have attempted to clarify the influence of protein malnutrition on the rate of vitamin A uptake from the blood by the liver or extrahepatic tissues or by both.

Expt 4. In this experiment the kinetics of vitamin A uptake by the liver were investigated after intravenous injection of a single dose of vitamin $A$ acetate. The results are presented in Fig. 4. Already Io min after the injection, the amount of vitamin A stored in the liver had attained a level of 2844 i.u., then decreased to increase again to a nearly equal value after $3 \mathrm{~h}$. The values at $\mathrm{I}$. min and $3 \mathrm{~h}$ after the injection differed to a highly significant extent from the intermediate values. The decrease in total vitamin A was obviously caused by the decrease of the amount of the vitamin in the alcohol form. Both in absolute amounts and as a percentage of the total liver vitamin $\mathrm{A}$, this form decreased continuously with time.

Expt 5. In this experiment the influence of protein restriction on the uptake of injected vitamin A acetate was examined. Already ro min after injection only a small part of the injected vitamin could be found in plasma as ester: most of it was already in the alcohol form (Table 3). As will be shown in the next experiment, the ester fraction, even at this time, was presumably almost completely made up of esters of long-chain fatty acids. The decrease in plasma vitamin A was delayed by protein 
malnutrition, but $24 \mathrm{~h}$ after injection the plasma levels were lower in the chicks fed at the two low protein levels than in the chicks fed on the $30 \%$ protein diet. The delayed decrease in plasma vitamin $\mathrm{A}$ in protein malnutrition was concomitant with a reduction of the percentage of vitamin A present in the alcohol form in the plasma.

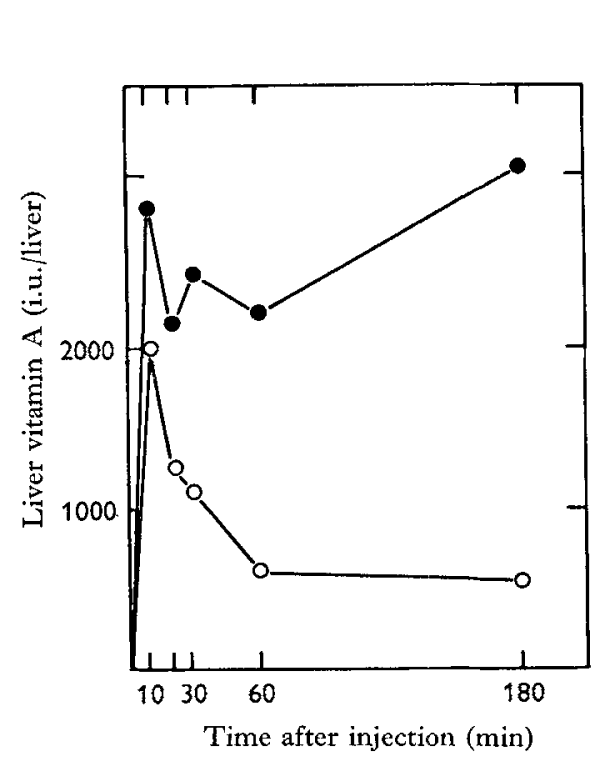

Fig. 4

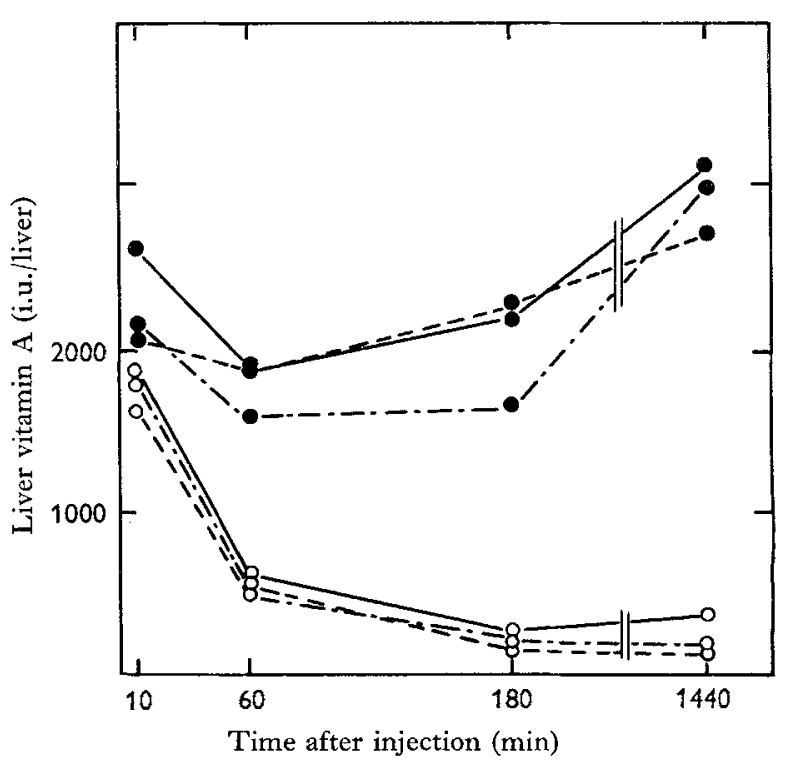

Fig. 5

Fig. 4. Expt 4. Amounts of vitamin A stored in the liver of chicks at different intervals after injection of roooo i.u. vitamin A acetate. All symbols as in Fig. I.

Fig. 5. Expt 5. Effect of the protein level in the diet of chicks on liver vitamin A content at different periods after the intravenous injection of roooo i.u. vitamin $A$ acetate in Tween 80 solution. - - - $5 \%$ dietary protein. All other symbols as in Fig. I.

Table 3. Expt 5. Effect of the level of protein in the diet of chicks on vitamin A content of plasma and kidney and its partition in the alcohol and ester forms at different periods after the intravenous injection of 10000 i.u. vitamin $A$ acetate in Tween 80 solution

\begin{tabular}{|c|c|c|c|c|c|c|}
\hline \multirow{2}{*}{$\begin{array}{c}\text { Interval } \\
\text { between } \\
\text { injection } \\
\text { and killing } \\
\text { (min) }\end{array}$} & \multirow{2}{*}{$\begin{array}{c}\text { Dietary } \\
\text { protein } \\
\text { level } \\
(\%)\end{array}$} & \multicolumn{3}{|c|}{ Vitamin $\mathrm{A}$ in $100 \mathrm{ml}$ plasma } & \multicolumn{2}{|c|}{ Vitamin A in kidney } \\
\hline & & $\begin{array}{l}\text { Body- } \\
\text { weight } \\
\text { (g) }\end{array}$ & $\begin{array}{l}\text { Total } \\
\text { (i.u.) }\end{array}$ & $\begin{array}{l}\text { Alcohol } \\
\text { as } \% \text { of } \\
\text { total }\end{array}$ & $\begin{array}{l}\text { Total } \\
\text { (i.u.) }\end{array}$ & $\begin{array}{l}\text { Alcohol } \\
\text { as \% of } \\
\text { total }\end{array}$ \\
\hline ro & $\begin{array}{r}30 \\
10 \\
5\end{array}$ & $\begin{array}{l}275 \\
232 \\
158\end{array}$ & $\begin{array}{l}1858 \\
1639 \\
3436\end{array}$ & $\begin{array}{l}83 \\
70 \\
58\end{array}$ & $\begin{array}{r}120 \\
85 \\
89\end{array}$ & $\begin{array}{l}84 \\
81 \\
82\end{array}$ \\
\hline 60 & $\begin{array}{r}30 \\
10 \\
5\end{array}$ & $\begin{array}{l}269 \\
226 \\
172\end{array}$ & $\begin{array}{l}410 \\
506 \\
733\end{array}$ & $\begin{array}{l}80 \\
78 \\
70\end{array}$ & $\begin{array}{l}87 \\
52 \\
53\end{array}$ & $\begin{array}{l}64 \\
3^{6} \\
65\end{array}$ \\
\hline I 80 & $\begin{array}{r}30 \\
\text { IO } \\
5\end{array}$ & $\begin{array}{l}293 \\
252 \\
16 I\end{array}$ & $\begin{array}{l}330 \\
402 \\
759\end{array}$ & $\begin{array}{l}54 \\
38 \\
28\end{array}$ & $\begin{array}{l}63 \\
44 \\
4 I\end{array}$ & $\begin{array}{l}42 \\
35 \\
45\end{array}$ \\
\hline $24 \mathrm{~h}$ & $\begin{array}{r}30 \\
\text { I0 } \\
5\end{array}$ & $\begin{array}{l}273 \\
243 \\
169\end{array}$ & $\begin{array}{l}179 \\
146 \\
170\end{array}$ & - & $\begin{array}{r}146 \\
33 \\
72\end{array}$ & $\begin{array}{l}23 \\
27 \\
24\end{array}$ \\
\hline
\end{tabular}


As in the previous experiments, the liver vitamin $A$ attained a maximum ro min after injection, to decrease after $60 \mathrm{~min}$ and to increase again after $24 \mathrm{~h}$ (Fig. 5). No consistent differences could be found in the liver stores of the chicks fed at the different protein levels. The concentration ratio was decreased by protein malnutrition from 10.6 to about 7.7 . As in the previous experiment, the amount of the vitamin in the ester form increased consistently with time, whereas the amount in the alcohol form showed the opposite trend. The percentage of vitamin A in the alcohol form also decreased consistently with time: this value was $70-80 \%$ ro min after injection, whereas $24 \mathrm{~h}$ after injection it was only I I $\%$ in the chicks fed at the $30 \%$ protein level and only $4 \%$ in the protein-deficient chicks, again showing the influence of protein restriction on this fraction of the vitamin. In an effort to clarify the fate of that part of the vitamin A which apparently left the liver after the initial deposition, the content of the vitamin in the kidneys was determined. This content showed a trend somewhat similar to the trend of the liver vitamin content, in as far as it showed a sudden rise (initial kidney stores, according to previous unpublished observations, could be estimated to be traces only), followed by a decrease and a new rise at $24 \mathrm{~h}$. However, the absolute amounts of the vitamin stored in the kidneys at any period were much too small to explain the decrease in the liver vitamin. Protein restriction decreased total kidney vitamin $A$ at all periods.

From the results shown, especially the high percentage of vitamin A alcohol found in plasma only ro min after injection, it may be concluded that vitamin A acetate is hydrolysed almost completely in the chick's body shortly after its injection. In agreement with these in vivo results, in vitro hydrolysis of vitamin A acetate by liver or kidney homogenates was quite high. Liver homogenates hydrolysed $28-30 \%$ of the substrate per mg protein under our standard conditions. Protein malnutrition did not influence this hydrolysing activity. Kidney homogenates also hydrolysed vitamin A acetate quite effectively. In this instance, protein malnutrition lowered the hydrolysing capacity from 27 to 20 and $19 \%$ in the chicks fed on the 30,10 and $5 \%$ protein diets respectively.

Expt 6. In this experiment the effect was tested of the form of vitamin A (alcohol or acetate) on plasma and liver contents after injection. Most parameters showed essentially the same trends when the two forms were injected. This applies to the continuous decrease with time in plasma vitamin A (Fig. 6A), to the amounts of vitamin stored in the liver (Fig. 6B) and to the percentage of liver vitamin $A$ in the alcohol form: when both forms were injected this percentage showed a continuous decrease from $74-82 \% 3 \mathrm{~min}$ after injection to $\mathrm{II}-12 \%$ after $24 \mathrm{~h}$. The decrease in total liver vitamin $A$ at the intermediate periods, which has already been shown in the previous experiments, was not found in the chicks given the alcohol form by injection, but could be clearly seen in the chicks given the acetate.

Paper chromatography of the vitamin A ester fraction from the livers of chicks given injections of vitamin $\mathrm{A}$ acetate showed that none of it could be found in the liver, even as early as $3 \mathrm{~min}$ after the injection. In plasma collected at the same time vitamin $\mathrm{A}$ acetate could still be found, whereas 7 min later, i.e. Io min after injection, only traces could be detected and none could be found afterwards. 
Expt 7. The effect was investigated of protein restriction on the kinetics of vitamin A uptake by the liver when vitamin A alcohol or palmitate was injected. Plasma vitamin A levels were much higher during the first $3 \mathrm{~h}$ after injection in the chicks given the palmitate (Table 4). Assuming that blood volume is $10 \%$ of body-weight and haematocrit about $35 \%$ (i.e. plasma volume about $6.5 \%$ of body-weight), the total amount of vitamin A found in the blood stream can be calculated. It is then found

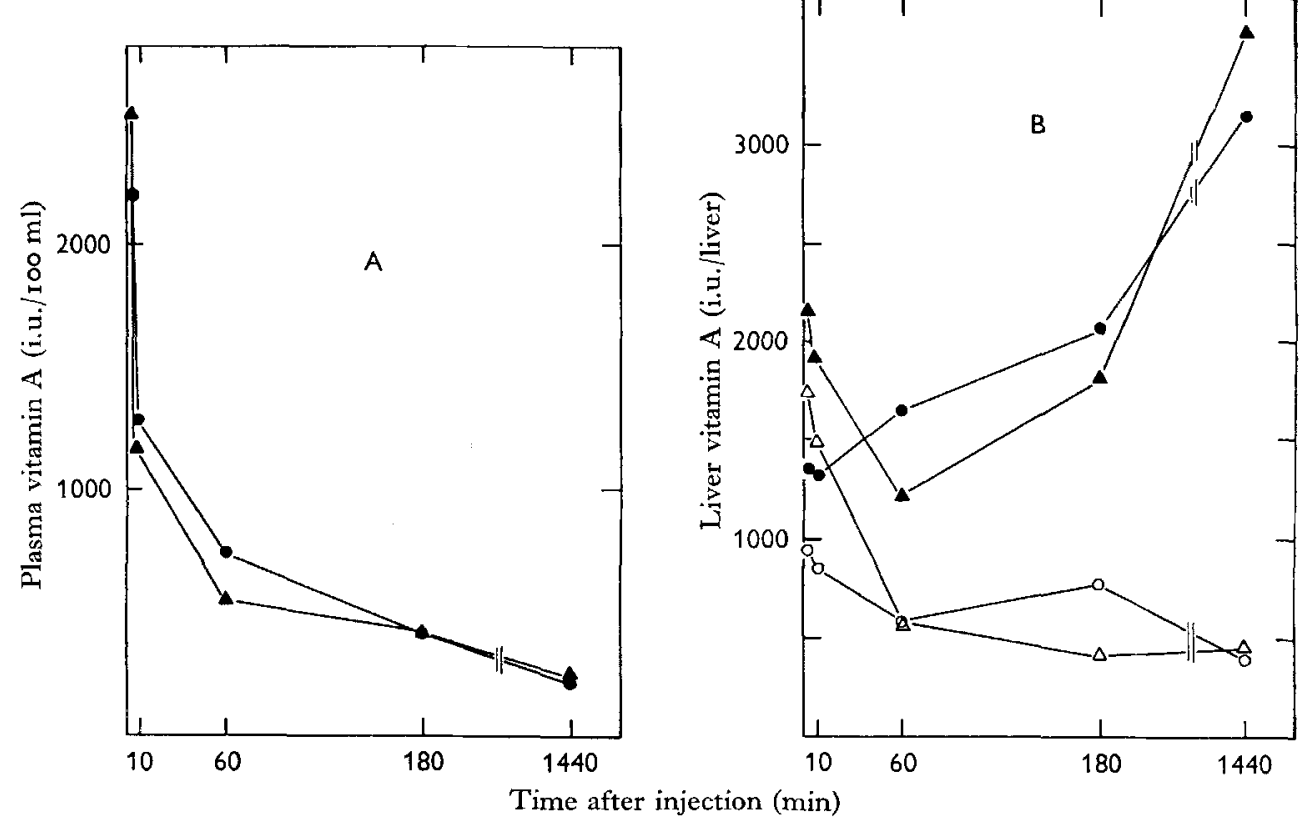

Fig. 6. Expt 6. Effect of form of vitamin A injected intravenously into chicks on vitamin A content $(A)$ in plasma and $(B)$ in liver at different periods after injection of 10000 i.u. vit umin $A$. $\boldsymbol{Q}, O$, vitamin $A$ alcohol injected; $\Delta, \triangle$, vitamin $A$ acetate injected. All other symbols as in Fig. 1 .

that 3 min after injection only $9 \%$ or I $1 \%$ of the dose was still in the blood stream of the chicks injected with the vitamin $\mathrm{A}$ alcohol and fed on the $30 \%$ or $10 \%$ protein diet respectively, whereas $55 \%$ or $64 \%$ of the dose was still in the blood stream of the chicks injected with the same amount of vitamin $A$ as palmitate. Obviously, the decrease of plasma vitamin $A$ is delayed when palmitate is injected as compared to the decrease when free vitamin $A$ is injected. Low dietary protein level also delayed somewhat the vitamin A clearance from plasma during the Ist hour after injection in the chicks injected with vitamin A alcohol. This dietary protein effect was not found when chicks were injected with vitamin A palmitate, presumably because uptake by liver was already so slow that protein malnutrition was no longer the limiting factor.

When vitamin A palmitate was injected, the percentage of plasma vitamin $A$ in the alcohol form was very low, but i $\mathrm{h}$ after injection the absolute amounts had already reached the same levels as in the chicks injected with vitamin A alcohol, because of the steep decrease of this fraction in the plasma of the latter chicks. 
When vitamin $\mathrm{A}$ alcohol was injected, liver vitamin $\mathrm{A}$ attained a maximum after injection and decreased at $60 \mathrm{~min}$ to increase again afterwards (Fig. 7). When vitamin A palmitate was injected a similar fluctuation could be seen in total liver vitamin $A$, but the process was delayed, and the reduction happened $3 \mathrm{~h}$ and not $\mathrm{I} \mathrm{h}$ after injection, as when vitamin $A$ alcohol was injected. The total amount of vitamin A stored in the liver of the chicks fed on the low-protein diet was lowered when either form of the

Table 4. Expt 7. Effect of form of vitamin $A$ injected and of the protein level in the diet of chicks on plasma vitamin $A$ content and on its partition in the ester and alcohol fractions at different periods after injection of 10000 i.u. vitamin $A$ alcohol or palmitate

\begin{tabular}{|c|c|c|c|c|c|}
\hline \multirow[b]{2}{*}{$\begin{array}{c}\text { Form of } \\
\text { vitamin } A \\
\text { injected }\end{array}$} & \multirow{2}{*}{$\begin{array}{l}\text { Interval } \\
\text { between } \\
\text { dosing and } \\
\text { killing } \\
\text { (min) }\end{array}$} & \multirow[b]{2}{*}{$\begin{array}{c}\text { Dietary } \\
\text { protein } \\
\text { level } \\
(\%)\end{array}$} & \multirow[b]{2}{*}{$\begin{array}{l}\text { Body- } \\
\text { weight } \\
\text { (g) }\end{array}$} & \multicolumn{2}{|c|}{ Vitamin $\mathrm{A}$ in $100 \mathrm{ml}$ plasma } \\
\hline & & & & $\begin{array}{l}\text { Total } \\
\text { (i.u.) }\end{array}$ & $\begin{array}{l}\text { Alcohol } \\
\text { as } \% \text { of } \\
\text { total }\end{array}$ \\
\hline \multirow[t]{2}{*}{-} & $\circ$ & 30 & $3^{23}$ & - & - \\
\hline & & 10 & 265 & - & -- \\
\hline \multirow[t]{9}{*}{ Alcohol } & 3 & 30 & 353 & $433 \mathrm{I}$ & $\begin{array}{l}87 \\
88\end{array}$ \\
\hline & IO & 30 & 357 & I 554 & $8 I$ \\
\hline & & Io & 205 & 3479 & 77 \\
\hline & 60 & 30 & 324 & 417 & 63 \\
\hline & & Io & 227 & 857 & 50 \\
\hline & I 80 & 30 & 296 & $3^{87}$ & $5^{8}$ \\
\hline & & 10 & 283 & 386 & 47 \\
\hline & $24 \mathrm{~h}$ & $3^{\circ}$ & 352 & 238 & $79^{*}$ \\
\hline & & 10 & 249 & 254 & $78 *$ \\
\hline \multirow[t]{10}{*}{ Palmitate } & 3 & 30 & $33^{\circ}$ & 25675 & 0.5 \\
\hline & & Io & 219 & $459 \mathrm{II}$ & 0.3 \\
\hline & IO & 30 & 310 & 28600 & 0.7 \\
\hline & & Io & $2 \mathrm{II}$ & 27031 & $I \cdot 5$ \\
\hline & 60 & 30 & 292 & I 5462 & $I \cdot 4$ \\
\hline & & 10 & 232 & 10005 & $6 \cdot I$ \\
\hline & 180 & 30 & 299 & 2840 & 6.8 \\
\hline & & 10 & 261 & 3695 & $6 \cdot 2$ \\
\hline & $24 \mathrm{~h}$ & 30 & 332 & 264 & $75^{*}$ \\
\hline & & IO & 262 & $37^{6}$ & $49^{*}$ \\
\hline
\end{tabular}

vitamin was injected, and the concentration ratio decreased accordingly. The percentage of liver vitamin $\mathrm{A}$ in the alcohol form decreased continuously with time when vitamin A alcohol was injected. After injection of vitamin A palmitate this percentage did not change during the first $3 \mathrm{~h}$ but declined later to reach, after $24 \mathrm{~h}$, about the same level as when the alcohol form was injected. Protein malnutrition slightly decreased this percentage. Pancreatic tissue and duodenal mucosa from chicks fed at different protein levels were used in in vitro assays to test the influence of this factor on hydrolysis and synthesis of vitamin A ester: the former activity was found to be depressed in both tissues by protein restriction and so was the esterification of 
vitamin A alcohol by duodenal mucosa, but the esterifying activity of the pancreas was not affected (Table 2).

Expt 8. Since the same weight ratio between vitamin $A$ and Tween was used in the preparation of the vitamin solutions, the vitamin A palmitate solutions contained greater amounts of detergent than the vitamin A alcohol solutions, in proportion to their respective molecular weights. The present experiment was carried out in order to ascertain if the amount of Tween injected and also if the type of feed given to the chickens had any effect on the vitamin A level in plasma after the intravenous injection of either vitamin A alcohol or palmitate. Plasma was taken from the chicks ro min

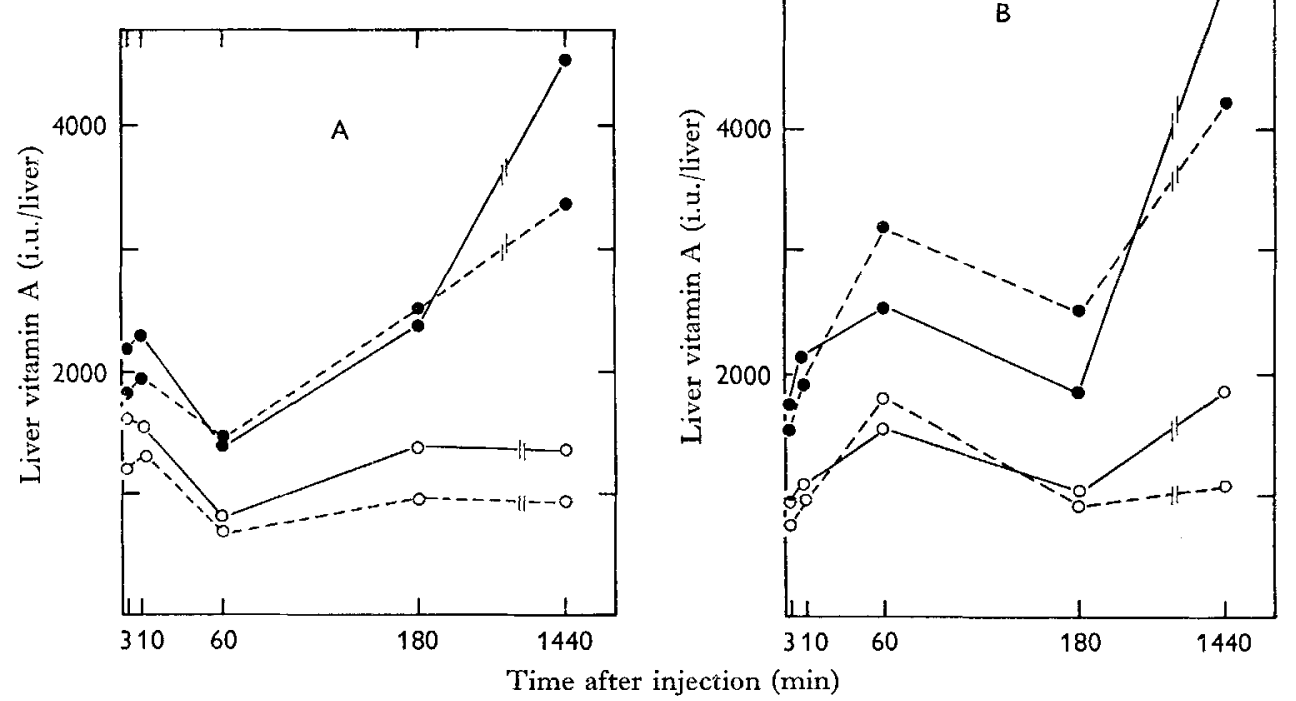

Fig. 7. Expt 7. Effect of form of vitamin A injected and of the protein level of the diet of chicks on liver vitamin $A$ at different periods after injection of roooo i.u. vitamin $A$ alcohol or palmitate. All symbols as in Fig. $\mathbf{r}$.

Table 5. Expt 8. Influence of type of feed, form of vitamin $A$ injected and amount of Tween 80 injected on the level of vitamin $A$ in plasma of chicks 10 min after intravenous injection of 10000 i.u. vitamin $A$

\begin{tabular}{|c|c|c|c|c|c|c|c|}
\hline \multirow[b]{2}{*}{$\begin{array}{c}\text { Form of } \\
\text { vitamin A } \\
\text { injected }\end{array}$} & \multirow[b]{2}{*}{$\begin{array}{l}\text { Type } \\
\text { of } \\
\text { feed* }\end{array}$} & \multirow[b]{2}{*}{$\begin{array}{c}\text { No. } \\
\text { of } \\
\text { chicks }\end{array}$} & \multirow{2}{*}{$\begin{array}{c}\text { Weight ratio } \\
\text { between } \\
\text { vitamin } A \\
\text { and Tween } 80 \\
\text { in the } \\
\text { solution }\end{array}$} & \multicolumn{4}{|c|}{ Plasma vitamin A } \\
\hline & & & & $\begin{array}{c}\text { Ester } \\
\text { (i.u./ } \\
\text { I00 ml) }\end{array}$ & $\begin{array}{c}\text { Alcohol } \\
\text { (i.u./ } \\
\text { I00 ml) }\end{array}$ & $\begin{array}{l}\text { Total } \\
\text { (i.u./ } \\
\text { I00 ml) }\end{array}$ & $\begin{array}{c}\text { Alcohol } \\
\text { as \% of } \\
\text { total }\end{array}$ \\
\hline \multirow[t]{2}{*}{ Alcohol } & $\mathrm{C}$ & 4 & IO & 325 & I I I 9 & I 444 & 77 \\
\hline & $\mathrm{S}$ & 4 & Io & 264 & 1012 & 1276 & 79 \\
\hline \multirow[t]{4}{*}{ Palmitate } & $\mathrm{C}$ & 2 & 5 & $22 I 8 I$ & 406 & 22587 & 2 \\
\hline & C & 2 & I5 & 24886 & I 73 & 25059 & I \\
\hline & $\mathrm{S}$ & 2 & 5 & 21640 & 222 & 21862 & I \\
\hline & $\mathrm{S}$ & 2 & I 5 & 30837 & 2331 & $33 \times 68$ & 6 \\
\hline
\end{tabular}


after injection. The results obtained were essentially the same as those in the previous experiments (Table 5) and confirmed that neither of the factors here examined was responsible for the differences found in plasma levels after the injection of different forms of the vitamin. It should perhaps be pointed out that the vitamin A palmitate solution with a Tween weight ratio of $\mathrm{I}_{5}: \mathrm{r}$ had an increasing effect on plasma vitamin $\mathrm{A}$ but of quite a different order from the one here considered.

\section{DISCUSSION}

The results presented here demonstrate that the hydrolysis of vitamin A palmitate in the intestine is a most important step in its process of absorption. Since the secretion of many enzymes by the pancreas is reduced in protein malnutrition (Behar, Arroyave, Tejada, Viteri \& Scrimshaw, 1956; Volk \& Lazarus, I960; Cavazetti \& Paradisi, r96r; McPhedron \& Lucas, 1960) it is to be expected that the pancreatic vitamin A esterases will be also affected. In fact, the hydrolysis of vitamin A palmitate in pancreas and duodenal mucosa homogenates in vitro was markedly reduced by protein malnutrition. We have shown in previous work (Nir \& Ascarelli, 1966, $1967 a, b)$ that factors decreasing vitamin A depletion from the liver, like low dietary protein level and thiouracil, lowered the vitamin A stored in the liver in the alcohol form. On the contrary, factors increasing vitamin A requirement, like adequate dietary protein level, thyroxine or high ambient temperature, increased this level.

Our findings are in accordance with those of Deshmukh et al. (1964). In their work it was reported that the activity of the two enzymes, the one hydrolysing and the other synthesizing vitamin A ester, in pancreas and intestinal mucosa of rats are markedly reduced on a low-protein diet. As has been pointed out in the previous paper (Nir et al. I 967 ), a comparison of their results with ours shows that chick tissues are more active in the hydrolysis of vitamin A palmitate than rat tissues. The possible implications of this difference were also pointed out. The decreased activity of the hydrolytic enzyme in chicks given a low-protein diet is also shown by the fact that, after dosing with vitamin A palmitate, the percentage of vitamin A present in the alcohol form in the small intestine was much lowered. However, this phenomenon may have also been caused in part by poorer absorption of the ester form by the intestinal mucosa. Poor hydrolysis of vitamin A palmitate in vivo was concomitant with decreased liver stores and concentration ratios. The importance of hydrolysis in the intestine in the preabsorptive phase is shown by the fact that, after dosing with vitamin $\mathrm{A}$ alcohol, protein malnutrition had no effect on absorption from the intestine or on liver storage at any period tested or on the concentration ratio. This is in spite of the lower esterifying activity in vitro, by incubation of duodenal mucosa, and in vivo, by analysis of the whole intestine.

The importance of the hydrolytic phase in the intestine is also shown by the fact that, when the intestine was by-passed by injecting vitamin A palmitate directly into the blood stream, the decrease of liver stores caused by protein malnutrition was much smaller. The form of the vitamin injected (alcohol, acetate or palmitate) in the blood did not influence the liver storage of the chicks fed on the low-protein diet. From the 
results obtained in the present work, the following conclusions can be drawn concerning the metabolic processes of vitamin A in blood: $(a)$ higher retention of vitamin $\mathrm{A}$ in blood, simultaneous with, and possibly caused by, the slower uptake of the vitamin by the liver and extrahepatic tissues, may reduce final liver stores, probably because of the lability of the circulating vitamin $A$ as compared to the stability of the vitamin $A$ stored in liver; $(b)$ the final liver stores, in normal chicks, obtained either after oral administration or after intravenous injection, are of the same order; this finding supports the assumption that the vitamin is destroyed mainly after its absorption from the intestine; $(c)$ the amount of vitamin A stored in the liver from vitamin A palmitate is higher than that stored from the alcohol, either when the vitamin is administered orally or when it is injected intravenously. It may well be that one of the causes of this improved storage is the higher stability of vitamin A palmitate as compared to vitamin A alcohol.

Protein malnutrition delayed the peak in plasma vitamin A level after an oral dose of palmitate and apparently reduced the clearance of the vitamin from the plasma. The high level of vitamin A in the plasma of chicks dosed with vitamin A alcohol and fed on a low-protein diet could result from a lowered uptake by tissues while the absorption rate from the intestine was not lowered. However, this lowered uptake could not be a limiting factor for the storing capacity because the final liver stores were not reduced in these chicks.

Blood lipoproteins are thought to be concerned with the transport of postabsorptive vitamin A ester (Krinsky, Cornwell \& Oncley, 1958). They are also known to be reduced in protein malnutrition (Olson, Jablonski \& Taylor, I958; Cravioto, de la Pena \& Burgos, I959). The levels of vitamin A found in the blood of our proteindeficient chicks dosed with vitamin A alcohol were higher than those in the chicks fed normally. This finding shows that the reduction of plasma lipoproteins, which probably accompanied feeding with our low-protein diet, was not a limiting factor in the utilization of orally administered vitamin A. Poor hydrolysis of esters in the intestine seems to be a much more important factor in protein malnutrition.

Protein malnutrition lowers the percentage of vitamin A alcohol in liver. The mechanism responsible for the equilibrium between the two forms of the vitamin has not yet been elucidated. Our study raises the possibility that extrahepatic tissues may also be involved in this equilibrium. The fluctuations in liver vitamin A content during the first hours after the intravenous injection of the vitamin show very clearly that vitamin A may leave the liver even while the process of deposition is in progress. Since the amount of the vitamin found in the liver in the ester form increased continuously, it may be inferred that the ester did not leave the liver, and that the reduction in liver stores was caused by migration of free alcohol to some other tissue. It seems that, after esterification in extrahepatic tissues, the esterified vitamin was returned to the blood and taken up again by the liver.

Possibly the vitamin captured by the liver tissue immediately after its injection becomes associated only in part with the specific lipoproteins concerned with its storage in the liver (Krishnamurthy, Mahadevan \& Ganguly, I958; Mahadevan, Krishnamurthy \& Ganguly, I959). It may well be that linkage of the vitamin in the 
liver with its specific lipoproteins is a slow process, slower than the capacity of the liver to capture the vitamin. It seems that there is an equilibrium between liver tissue and body fluids, which regulates the concentration of the non-linked vitamin $A$ in liver. In fact, the lowering of the vitamin A level in the liver occurred when plasma levels were consistently lowered. When vitamin A palmitate was injected, the decrease of vitamin A in plasma was delayed, and so was the migration of the non-linked vitamin $A$ from the liver.

When vitamin A acetate was injected, this form could not be found in the chicks' plasma or in their liver so min after the injection. This explains why plasma and liver vitamin $\mathrm{A}$ were similar in chicks injected with either vitamin A acetate or alcohol. On the contrary, when vitamin A palmitate was injected the clearance of the ester form from the plasma was much slower. This finding points to the existence in the chick of two different enzymes concerned with the hydrolysis of vitamin A acetate and palmitate. The existence of two such enzymes in rat liver was shown in vitro by Mahadevan, Ayyoub \& Roels (1966). The differences in enzymic activity in the different organs reported in our previous work (Nir et al. 1967) confirmed their assumption. The in vivo observations here presented supply further evidence of the existence of the two above-mentioned enzymes.

The authors wish to thank Hoffmann-La Roche and Co., Basle, for the gift of pure vitamin $\mathrm{A}$ alcohol, acetate and palmitate, and Chas. Pfizer and Co. Inc., New York, for the gift of water-dispersible vitamin A palmitate.

This work was financed by grant FG-Is-I35 from the US Department of Agriculture.

\section{REFERENCES}

Ames, S. R., Risley, H. A. \& Harris, P. L. (1954). Analyt. Chem. 26, I378.

Behar, M., Arroyave, G., Tejada, C., Viteri, F. \& Scrimshaw, N. S. (1956). Revta Col. méd. Guatem. 7 , $22 \mathrm{I}$.

Cavazetti, F. \& Paradisi, F. (196r). Archs Sci. méd. rrr, 245.

Cravioto, J., de la Pena, C. L. \& Burgos, G. (I959). Metabolism 8, 722.

Deshmukh, D. S., Malathi, P. \& Ganguly, J. (I964). Biochem. F. 9o, 98.

Gornall, A. G., Bardawill, C. J. \& David, N. M. (1949). F. biol. Chem. 177, 75 I.

Jungalwala, F. B. \& Cama, H. R. (1962). F. Chromat. 8, 535.

Krinsky, N. I., Cornwell, D. G. \& Oncley, J. L. (1958). Archs Biochem. Biophys. 73, 233.

Krishnamurthy, S., Mahadevan, S. \& Ganguly, J. (1958). F. biol. Chem. 233, 32.

McPhedron, N. T. \& Lucas, C. C. (I 960). Surg. Forum II, 369 .

Mahadevan, S., Ayyoub, N. I. \& Roels, O. A. (1966). 9. biol. Chem. 241, 57.

Mahadevan, S., Krishnamurthy, S. \& Ganguly, J. (1959). Indian F. med. Res. 47, I 99.

Nir, I. \& Ascarelli, I. (1966). Br. ₹. Nutr. 20, 4I.

Nir, I. \& Ascarelli, I. (1967a). Br. 7. Nutr. 21, I67.

Nir, I. \& Ascarelli, I. (1967b). Br. Poult. Sci. 7, 297.

Nir, I., Bruckental, I. \& Ascarelli, I. (I967). Br. F. Nutr. 21, 557.

Olson, R. E., Jablonski, J. R. \& Taylor, E. (r958). Am. F. cl* Nutr. 6, I I I.

Volk, B. W. \& Lazarus, S. S. (r960). Am. F. Path. 37, I21. 